\title{
Reconstructing overfishing: Moving beyond Malthus for effective and equitable solutions
}

Elena M Finkbeiner ${ }^{1,2}$ Nathan J Bennett ${ }^{2,3,4}$ Timothy H Frawley ${ }^{1}$ Julia G Mason $^{1}$ Dana K Briscoe ${ }^{1}$ Cassandra M Brooks ${ }^{5}$ Crystal A Ng ${ }^{1}$ Rosana Ourens ${ }^{1}$ Katherine Seto ${ }^{6}$ Shannon Switzer Swanson ${ }^{5}$ Jose Urteaga $^{5}$ Larry B Crowder ${ }^{1,2}$

1. Hopkins Marine Station, Stanford University, Pacific Grove, CA, USA

2. Center for Ocean Solutions, Stanford University, Monterey, CA, USA

3. Institute for Resources Environment and Sustainability, University of British Columbia, Vancouver, BC, Canada

4. School of Marine and Environmental Affairs, University of Washington, Seattle, WA, USA

5. School of Earth, Energy and Environmental Sciences, Stanford University, Stanford, CA, USA

6. College of Natural Resource, University of California Berkeley, Berkeley, CA, USA

\section{Correspondence}

Elena M Finkbeiner, Hopkins Marine Station, Stanford University, Pacific Grove, CA, USA. Email: elenamf@stanford.edu

This is the peer reviewed version of the following article: Finkbeiner EM, Bennett NJ, Frawley TH, et al. Reconstructing overfishing: Moving beyond Malthus for effective and equitable solutions. Fish Fish. 2017;18:1180-1191, which has been published in final form at https://doi.org/10.1111/faf.12245. This article may be used for non-commercial purposes in accordance with Wiley Terms and Conditions for Self-Archiving.

\section{Abstract}

Inaccurate or incomplete diagnosis of the root causes of overfishing can lead to misguided and ineffective fisheries policies and programmes. The "Malthusian overfishing narrative" suggests that overfishing is driven by too many fishers chasing too few fish and that fishing effort grows proportionately to human population growth, requiring policy interventions that reduce fisher access, the number of fishers, or the human population. By neglecting other drivers of overfishing that may be more directly related to fishing pressure and provide more tangible policy levers for achieving fisheries sustainability, Malthusian overfishing relegates blame to regions of the world with high population growth rates, while consumers, corporations and political systems responsible for these other mediating drivers remain unexamined. While socialecological systems literature has provided alternatives to the Malthusian paradigm, its focus on institutions and organized social units often fails to address fundamental issues of power and politics that have inhibited the design and implementation of effective fisheries policy. Here, we apply a political ecology lens to unpack Malthusian overfishing and, relying upon insights derived from the social sciences, reconstruct the narrative incorporating four exemplar mediating 
drivers: technology and innovation, resource demand and distribution, marginalization and equity, and governance and management. We argue that a more nuanced understanding of such factors will lead to effective and equitable fisheries policies and programmes, by identifying a suite of policy levers designed to address the root causes of overfishing in diverse contexts.

\section{Introduction}

Numerous studies of overfishing paint a dismal portrait of the future of marine fisheries (Essington, Beaudreau, \& Wiedenmann, 2006; Jackson et al., 2001; Pauly, Christensen, Dalsgaard, Froese, \& Torres, 1998; Worm et al., 2006), although in some geographies, ecologies, and developmental contexts, the impacts have been worse than in others (Hilborn, 2007; Worm et al., 2009). These narratives of overfishing are often substantiated, both explicitly and implicitly, by a very particular explanation of the relationship between humans and the environment: there are "too many fishers chasing too few fish" (Pauly, 1990), inevitably leading to a "tragedy of the commons" (Gordon, 1954; Hardin, 1968).

We refer to this dominant explanation about the causes of overfishing as the "Malthusian overfishing narrative," acknowledging Thomas Malthus whose seminal work, "An Essay on the Principle of Population" advances the theory that unchecked human population growth will outpace resources leading to increasing poverty (Malthus, 1798) (Table 1). A similar line of thinking emerged from "neo-Malthusians" in the middle of the 20th century, as they predicted that overpopulation of the planet would lead to the destruction of the environment (Ehrlich, 1968; Meadows, 1972; Osborn, 1948; Vogt, 1948). Some decades later, fisheries scientists adopted such discourse to help explain the decline of global fisheries (Pauly, 1990; Roberts, 1995). The problem of Malthusian overfishing is generally relegated to regions of the world characterized by positive population growth, high poverty levels, and strong dependence on marine resources, where short-term needs may undermine long-term conservation goals (Jackson, 2001; McClanahan, Hicks, \& Darling, 2008; Worm \& Branch, 2012). Similarly, it is often argued that overfishing is intricately tied to human population growth vis-à-vis an influx of the "landless poor" into the fisheries sector (Pauly, 1990, 2006).

While there is no denial that human population growth can exert pressure on natural resources around the world (Johnson et al., 2017; McKee, Sciulli, David Fooce, \& Waite, 2004; Vitousek, Mooney, Lubchenco, \& Melillo, 2008), attributing all the blame to global or local population growth is simply inaccurate (Allison, 2001; Robbins, 2011). The oversimplified linear population-environment relationship is problematic (Durham, 1995; Gray \& Moseley, 2005; Oldham, 2006), ignoring many other rigorously studied and well-supported factors (i.e. migration, technology, wealth, consumption, markets, governance structures and power) (Borgerhoff-Mulder \& Copolillo, 2005; Steneck, 2009; Toth \& Szigeti, 2016). In this paper, we argue that attributing overfishing to Malthusian population-environment dynamics omits or conceals important mediating drivers of overfishing, unfairly blames fishers in the small-scale sector particularly from developing countries, and diverts accountability from net importers of seafood who benefit from and even drive increased fisheries harvest. This omission can lead to the creation of systematic winners and losers on a global scale and inhibit the development of sustainable fisheries policies. 
Table 1. Timeline of Malthusian discourses

\begin{tabular}{|c|c|c|c|}
\hline Era & Time & Quotes & Description \\
\hline Malthusianism & $\begin{array}{l}19^{\text {th }} \\
\text { Century }\end{array}$ & $\begin{array}{l}\text { "Population, when unchecked, increases in a geometrical } \\
\text { ratio. Subsistence only increases in an arithmetical } \\
\text { ratio... The means of subsistence, under circumstances the } \\
\text { most favorable to human industry, could not possibly be } \\
\text { made to increase faster than in an arithmetical ratio" } \\
\text { (Malthus, 1798). }\end{array}$ & $\begin{array}{l}\text { Populations tend to increase faster } \\
\text { than the supply of food available } \\
\text { for their needs. Poverty and famine } \\
\text { are natural outcomes of population } \\
\text { growth and function as preventive } \\
\text { "checks" on the lower classes to } \\
\text { maintain the balance between } \\
\text { production and reproduction. }\end{array}$ \\
\hline $\begin{array}{l}20^{\text {th }} \text { century } \\
\text { Neo- } \\
\text { Malthusianism }\end{array}$ & $\begin{array}{l}\text { 1940s- } \\
1980 \text { s }\end{array}$ & $\begin{array}{l}\text { "Parts of the earth, once living and productive, have thus } \\
\text { died at the hand of man. Others are now dying. If we cause } \\
\text { more to die, nature will compensate for this in her own } \\
\text { way as she has already begun to do.... [the] eventual } \\
\text { results, if present ways remain uncorrected, point to } \\
\text { widespread misery such as human beings have not yet } \\
\text { experienced, and threaten, at the end of the day, every } \\
\text { man's survival" (Osborn, 1948). } \\
\text { "We must rapidly bring the world population under } \\
\text { control, reducing the growth rate to zero or making it } \\
\text { negative. Conscious regulation of human numbers must be } \\
\text { achieved. Simultaneously we must, at least temporarily, } \\
\text { greatly increase our food production" (Ehrlich, 1968). }\end{array}$ & $\begin{array}{l}\text { Existing human populations are not } \\
\text { being fed properly and it is } \\
\text { unreasonable to expect the } \\
\text { advancements in production } \\
\text { required to remedy the problem. } \\
\text { Population control programmes are } \\
\text { necessary to ensure resources for } \\
\text { current and future populations. }\end{array}$ \\
\hline $\begin{array}{l}\text { Tragedy of } \\
\text { common-pool } \\
\text { resources }\end{array}$ & $\begin{array}{l}\text { 1950s- } \\
1970 \mathrm{~s}\end{array}$ & $\begin{array}{l}\text { "There appears to be some truth in the conservative dictum } \\
\text { that everybody's property is nobody's property. Wealth } \\
\text { that is free for all is valued by one because he who is } \\
\text { foolhardy enough to wait for its proper time of use will } \\
\text { only find that it has been taken by another... The fish in } \\
\text { the sea are valueless to the fisherman, because there is no } \\
\text { assurance that they will be there for him tomorrow if they } \\
\text { are left behind today" (Gordon, 1954). } \\
\text { "Each man is locked into a system that compels him to } \\
\text { increase his herd without limit-in a world that is limited. } \\
\text { Ruin is the destination toward which all men rush, each } \\
\text { pursuing his own best interest in a society that believes in } \\
\text { the freedom of the commons. Freedom in a commons } \\
\text { brings ruin to all" (Hardin, 1968). }\end{array}$ & $\begin{array}{l}\text { Under circumstances characterized } \\
\text { by a lack of property rights or } \\
\text { external intervention, individual } \\
\text { users acting according to their own } \\
\text { self-interest will increase their } \\
\text { consumption at the expense of the } \\
\text { common good, directly harming } \\
\text { others who can no longer enjoy the } \\
\text { benefits. }\end{array}$ \\
\hline $\begin{array}{l}\text { Malthusian } \\
\text { Overfishing }\end{array}$ & $\begin{array}{l}\text { 1990- } \\
\text { Present }\end{array}$ & $\begin{array}{l}\text { "Poor fishermen, faced with declining catches and lacking } \\
\text { any other alternative, [may] initiate wholesale resource } \\
\text { destruction in their effort to maintain their incomes.... } \\
\text { Malthusian overfishing will cause human misery so long } \\
\text { as small-scale fisheries are perceived of, and } \\
\text { operationalized as excess labor dumps" (Pauly, 1990). } \\
\text { "Throughout large areas of the developing world human } \\
\text { populations have been expanding, leading to rapidly } \\
\text { increasing pressure on limited resources. On reefs this has } \\
\text { resulted in fishing levels and methods that cause wholesale } \\
\text { resource destruction. Fine-mesh nets, weights scare lines, } \\
\text { poisons, and dynamite are all employed in an overfishing } \\
\text { spiral in which more and more fishers chase fewer and } \\
\text { fewer fish" (Roberts, 1995). }\end{array}$ & $\begin{array}{l}\text { Fishing effort, the use of } \\
\text { competitive and destructive gear } \\
\text { types, and declining resources } \\
\text { increase in proportion to human } \\
\text { population growth, migration into } \\
\text { the fishing sector, and poverty. }\end{array}$ \\
\hline $\begin{array}{l}\text { Fisheries } \\
\text { Doom and } \\
\text { Gloom }\end{array}$ & $\begin{array}{l}2000- \\
\text { Present }\end{array}$ & $\begin{array}{l}\text { "Most fishing is unsustainable because...inexorable } \\
\text { growth of the human population drives increasing } \\
\text { demand..." (Jackson, 2001). } \\
\text { "Human-dominated marine ecosystems are experiencing } \\
\text { accelerating loss of populations and species."; "Data } \\
\text { highlight the societal consequences of an ongoing erosion } \\
\text { of diversity that appears to be accelerating on a global } \\
\text { scale. This trend is of serious concern because it projects } \\
\text { the global collapse of all taxa currently fished by the mid- } \\
21 \text { st Century" (Worm et al., 2006). }\end{array}$ & $\begin{array}{l}\text { Increasing worldwide population } \\
\text { and human impact has resulted in } \\
\text { increasing exploitation of fisheries } \\
\text { resources, environmental } \\
\text { degradation and decreases in } \\
\text { human well-being that constitute a } \\
\text { global fisheries crisis. Intense } \\
\text { marine wildlife declines over the } \\
\text { past century are contributing to a } \\
\text { modern ocean era of mass } \\
\text { extinction. }\end{array}$ \\
\hline
\end{tabular}


It bears noting that various alternative narratives have emerged in contrast to the Malthusian perspective. For example, social-ecological systems scholars have used fisheries as model systems to refute the inevitability of Hardin's tragedy of the commons, referencing the capacity of fishing communities to self-govern their marine resources in the absence of external intervention or privatization (Basurto, 2005; Berkes, 2003; Berkes \& Folke, 1998; Dietz, Ostrom, \& Stern, 2003; Ostrom, 1990). Such research has made significant progress in advancing our understanding of the human dimensions of environmental change, although the field has been criticized for its failure to incorporate insight derived from anthropology and political ecology to address issues concerning power and politics (Cote \& Nightingale, 2012; Fabinyi, Evans, \& Foale, 2014). While political ecology has made major contributions to terrestrial conservation and resource management by challenging the Malthusian perspective (e.g. Blaikie \& Brookfield, 2015; Robbins, 2011), in the context of fisheries, the discipline has largely focused on critiquing management reforms towards centralization, capitalization and privatization of marine resources (Bromley, 2009; Carothers, 2010; Fabinyi, 2013; Mansfield, 2007; Nayak, Oliveira, \& Berkes, 2014; Pinkerton \& Edwards, 2009; St Martin, 2007).

Encouragingly, some fisheries scholars have begun to consider and empirically evaluate additional factors beyond population growth (Cinner et al., 2016). Nevertheless, others working in academic and policy realms continue to rely upon the Malthusian explanation, either explicitly or implicitly, without rigorously testing its core assumptions (Figure 1). The purpose of this paper is to acknowledge and build from the burgeoning body of literature challenging the simplistic notion of population growth and overfishing and synthesize a more holistic understanding of the complex drivers of overfishing. Understanding how these drivers manifest at local and regional scales will enable the creation of more comprehensive fisheries policies and programmes in diverse social-ecological contexts.

Spectrum of contemporary Malthusian overfishing treatments:

From empirical hypothesis testing to Population-Health-Environment initiatives

\begin{tabular}{|c|c|c|}
\hline $\begin{array}{l}\text { Empirical analysis } \\
\text { challenging } \\
\text { contemporary } \\
\text { narrative }\end{array}$ & $\begin{array}{l}\text { Contemporary } \\
\text { narrative of } \\
\text { Malthusian } \\
\text { overfishing }\end{array}$ & $\begin{array}{c}\text { Conservation } \\
\text { programs based on } \\
\text { contemporary } \\
\text { narrative }\end{array}$ \\
\hline $\begin{array}{l}\text { "Importantly, bright spots } \\
\text { [healthy coral reefs] are not } \\
\text { simply comprised of remote } \\
\text { areas with low fishing pressure; } \\
\text { they include localities where } \\
\text { human populations and use of } \\
\text { ecosystem resources is high, } \\
\text { potentially providing insights } \\
\text { into how communities have } \\
\text { successfully confronted strong } \\
\text { drivers of change." } \\
\text { (Cinner et al. 2016) }\end{array}$ & $\begin{array}{l}\text { "Our long experience of } \\
\text { observing coastal resource } \\
\text { degradation indicates that the } \\
\text { only long-term solutions will be } \\
\text { through combating poverty and } \\
\text { population growth in developing } \\
\text { countries..." } \\
\text { (Wilkinson and Salvat 2012) }\end{array}$ & $\begin{array}{l}\text { "From the perspective of } \\
\text { biodiversity conservation the } \\
\text { results are equally persuasive, } \\
\text { as the reduction in direct } \\
\text { anthropogenic pressure on the } \\
\text { region's dwindling marine and } \\
\text { coastal resources brought about } \\
\text { by this [Population-Health- } \\
\text { Environment] project will be } \\
\text { instrumental in the conservation } \\
\text { of Velondriake's marine and } \\
\text { coastal ecosystems." } \\
\text { (Harris et al. 2012) }\end{array}$ \\
\hline
\end{tabular}

Marine conservation challenges are increasingly addressed through coupling conservation programs with family planning initiatives, as seen through a burgeoning number of Population-Health-Environment programs. At the same time, Malthusiar assumptions are now being empirically tested in large-scale analyses, providing evidence that marine resource degradation is often more correlated with other social processes than population growth and human density.

Figure 1. Spectrum of contemporary Malthusian overfishing treatments: from empirical hypothesis testing to population- health-environment initiatives. 
Using a political ecology lens, we begin by critically examining the "Malthusian overfishing narrative" and unpacking several important issues that are either neglected or deprioritized by this simplified explanation. We then reconstruct the narrative of overfishing as a complex process by exploring four representative (but by no means exhaustive) mediating drivers of fishing effort where issues of power and politics are particularly salient: technology and innovation (e.g. Boserup, 1965; Jenkins, 2010; Kremer, 1993), demand and distribution (e.g. Bennett, Govan, \& Satterfield, 2015; Österblom et al., 2015; Swartz, Rashid Sumaila, Watson, \& Pauly, 2010), marginalization and equity (e.g. Bene, 2003; Fabinyi, 2013; Nayak et al., 2014), and governance and management (e.g. Cinti, Shaw, Cudney-Bueno, \& Rojo, 2010; Hauck, 2008; Raemaekers et al., 2011) (Figure 2). To conclude, we discuss important policy levers that might be employed to pragmatically address the root causes of overfishing in diverse contexts.

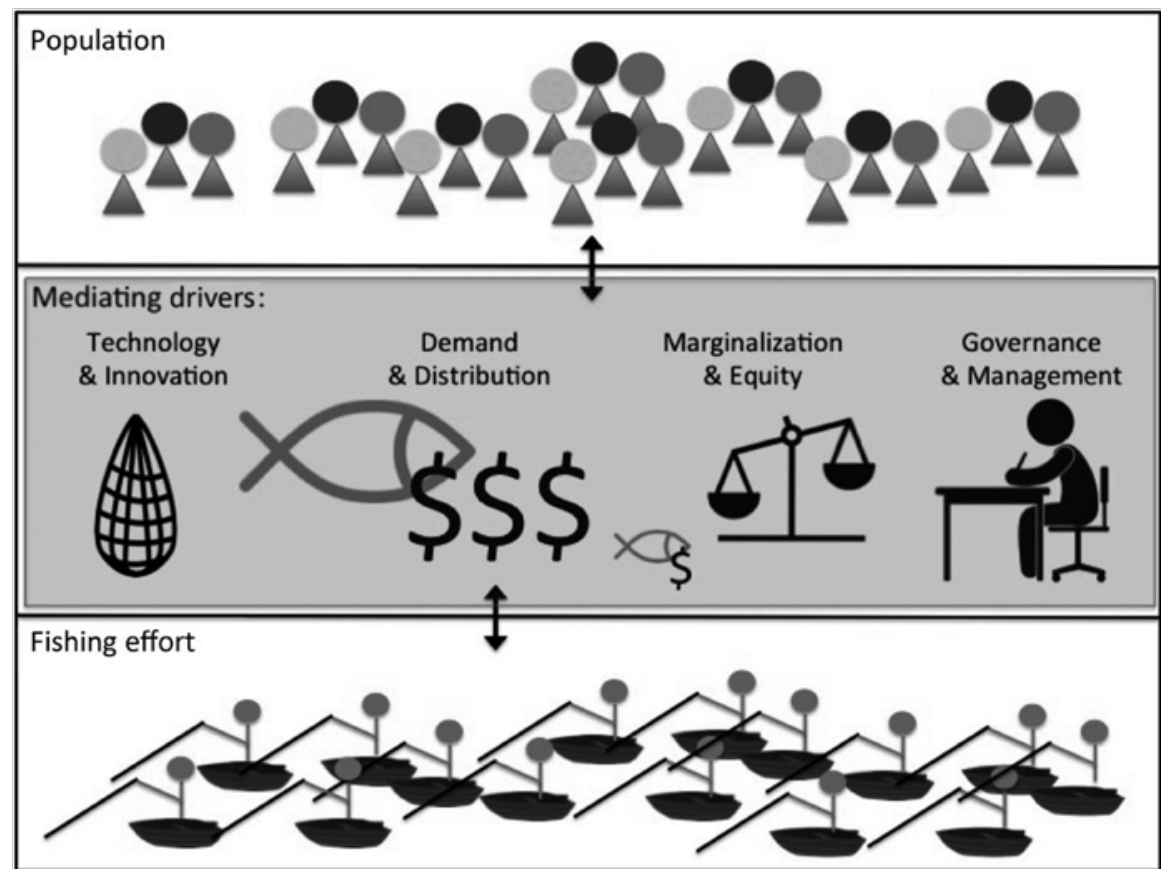

Figure 2. Reconstructing Malthusian overfishing. Examples of drivers mediating and expanding the relationship between population growth and fishing effort.

\section{Deconstructing Malthusian Overfishing}

\subsection{In this narrative, who is implicated as responsible and subsequently marginalized?}

The Malthusian framing of overfishing implicates fishers in regions that exhibit positive population growth rates, with open-access fisheries, and few alternative livelihood opportunities. Meanwhile, the solutions to this crisis are seen as the purview of "experts"- - largely the western scientists and NGOs who have been involved in, and responsible for, crafting the framing itself. In addition to small-scale fishers, women have also increasingly been implicated in Malthusian overfishing (Lohmann, 2003). Specifically, since Malthusian overfishing is driven by growth of both fishing populations and fish consumers (Pauly, 1994), women's productive and reproductive roles have become increasingly targeted for conservation interventions (Harris, Mohan, Flanagan, \& Hill, 2012; Hartmann, 2004; Newman, Fisher, Mayhew, \& Stephenson, 2014). 


\subsection{What policy prescriptions are advocated as a result of this narrative?}

Malthusian overfishing involves a specific narrative concerning the origin and evolution of the overfishing problem, and a certain set of policies are often prescribed in response. For example, given its explicit emphasis on global and local population growth, family planning initiatives developed by population-health-environment (PHE) partnerships have increasingly become an area of focus for addressing overfishing and other environmental issues (Evans, 2016; Harris et al., 2012; Johnson \& Nurick, 1995; Oglethorpe, Honzak, \& Margoluis, 2008). Likewise, the Malthusian narrative characterizes the fishing sector as an excess labour dump and thus advocates for the promotion of alternative livelihoods (Pauly, 1994; Smith, 1979).

Malthusian discourse is also implicitly coupled with bioeconomic discourse in how they inform fisheries policy. Bioeconomic discourse suggests that in formally "unregulated" fisheries, fishing effort will always increase well past maximum sustainable yield (MSY) until the fishery is no longer profitable (Gordon, 1954). Likewise, Garrett Hardin (1968) prophesized that any common-pool resource left to the devices of resource users themselves will face inevitable overexploitation. The confluence of these discourses suggests that too many fishers chasing too few fish should be addressed by top-down restrictions on fishing effort, or by "privatizing" fisheries resources through allocation of formal rights. In other words, policies have focused on effort reductions and restricted access through a variety of mechanisms. Two such examples are exclusive rights (i.e. catch shares, territorial use rights and limited entry licenses) and preservation (i.e. protected areas, no-fishing reserves).

\subsection{Is this narrative effective at solving the overfishing crisis?}

Policy interventions linked to the Malthusian narrative may be effective at solving the overfishing crisis, if indeed population growth or an excess labour force is the primary driver, and equitable policies are crafted carefully with explicit attention to the local context and access. For example, territorial use rights in the context of the Philippines (Pomeroy, Pollnac, Katon, \& Predo, 1997), Chile (Gelcich, Kaiser, Castilla, \& Edwards-Jones, 2008) and Mexico (Micheli et al., 2012) have enhanced ecological and social outcomes for some small-scale fishers. Marine protected areas in American Samoa have also brought benefits to small-scale fisheries, particularly when sociocultural context is considered in the process of design and implementation (Fiske, 1992). However, if the problem is misdiagnosed as Malthusian, or when policies are poorly designed, the aforementioned "prescriptions" may instead lead to perverse outcomes that ultimately undermine the goal of curbing overfishing.

For example, exclusion measures such as catch shares do not always lead to reductions in catch, but can instead consolidate catch within a restricted number of vessels (Bromley, 2009; Pinkerton \& Edwards, 2009), forcing many others out of the fishery, or to fish illegally (Raemaekers et al., 2011). Likewise, protection measures such as marine protected areas (MPAs) may lead to increased fishing pressures just outside of the MPA boundaries or in the broader seascape (Lele, Wilshusen, Brockington, Seidler, \& Bawa, 2010). Furthermore, when these interventions are top-down, failing to include local community members during design and implementation phases, this can result in alienating local community members, undermining legitimacy and creating opposition rather than fostering potential conservation allies (Bennett \& Dearden, 2014; Campbell, 1999; Lele et al., 2010). Perverse outcomes from alternative 
livelihood programmes can include the reinvestment of income into fishing livelihoods, leading to increased pressure on the resource (Pollnac \& Poggie, 2008; Torell, Crawford, Kotowicz, Herrera, \& Tobey, 2010). Although PHE programmes targeted towards marine conservation are relatively new, some experts are sceptical about whether or not participating women have a full and informed choice with regard to the family planning measures applied and are concerned with the potential health concerns associated with such interventions (Evans, 2016).

In sum, in certain cases it is unlikely that policies driven by the Malthusian narrative can comprehensively address the complexities of the overfishing problem. Furthermore, prescriptions advocated from a Malthusian perspective often alienate and exclude fishers and fish- workers who most closely depend on and interact with the resource. In other words, many fishing communities are forced to incur most of the costs associated with such policy prescriptions while the benefits go to others. Such sociopolitical marginalization can trigger a cascade of undesirable reactions and outcomes in the marine environment.

\section{Reconstructing Overfishing as a Complex Process}

How can we recast this oversimplified narrative into a more nuanced and productive dialogue to address the underlying problem? The goal of this next section is to reconstruct overfishing as a complex process, without ignoring the linkages to human population growth, but with more explicit attention to mediating drivers of fishing effort (Figure 2). Recognizing that fishing effort is driven by diverse socio-institutional conditions and processes (Bene, 2003), we will focus on four examples of mediating drivers where issues of power and politics are relevant: (i) technology and innovation, (ii) demand and distribution, (iii) marginalization and equity, and (iv) governance and management. These four drivers are intended as high-level, inclusive examples, well represented in the literature, and pertinent across a variety of contexts, rather than an exhaustive characterization of overfishing. We use "drivers" here for simplicity, but recognize that these are elements of complex systems and as such may also be outcomes or dynamic feedbacks. As seen in Table 1, exact treatment of the Malthusian overfishing discourse has evolved over time, sometimes implicitly acknowledging other mediating drivers. The novel contribution of this narrative reconstruction is to unpack and elevate these drivers, and link them to tangible policy levers to curb overfishing.

\subsection{Technology and innovation}

Technology, the most immediate driver of fishing pressure, decouples the relationship between human population growth and fishing impacts through breakthroughs in fishing efficiency. Technological changes and innovation have long provided counterarguments to Malthusian narratives (Boserup, 1965) — indeed, the blue revolution of aquaculture production parallels the green revolution that supplied agricultural yields beyond Malthus's wildest imagining (CostaPierce, 2008), with important caveats. We do not argue that technological advances "solve" Malthusian resource pressures; rather we present technology and innovation as a double-edged sword that can increase overfishing or promote sustainability.

On one edge of the sword, technology has increased catch efficiency and decreased fish stocks for as long as humans have fished (Pitcher, 2001). From baited hooks and outboard motors to mechanized trawls, monofilament nets and deep-water gear, technological advances have increased fishing impacts disproportionate to population growth. Larger boats have also meant 
that fisheries have moved into deeper waters and areas further from shore while more advanced fish finding technologies assist in locating stocks (Morato, Watson, Pitcher, \& Pauly, 2006; Watson et al., 2015). On the other edge of the sword, technology can mitigate fishing pressure and promote ecosystem health. For example, by-catch-reduction technology reduces the impacts of shrimp trawling by releasing juvenile fish and endangered sea turtles from nets (Kennelly \& Broadhurst, 2002). Advances in aquaculture technology that increase production and reduce environmental impacts may potentially transfer the burden of protein production from wild stocks (so long as research and development continues to find more efficient ways for producing aquaculture feed (Bene et al., 2015)). Technological solutions to enforcement and seafood traceability - major challenges for combating illegal, unregulated and unreported fishing - are emerging through innovations in surveillance and tracking (O'Shea \& Thompson, 2006; Presidential Task Force 2015).

Policy interventions cannot effectively address technology in a vacuum, since it is linked to other intermediate drivers we describe below: resource demand drives mechanization (Boserup, 1965; Kremer, 1993), and governance and management regulate technology. Technology and access to technology can create power differentials and inequality, thus entrenching marginalization and poverty (Pauly, 2006). Differential access to more efficient technology like mechanized boats or onboard processing creates a positive feedback loop of inequality as those with access receive higher returns while depleting resources and driving down prices for those without such access. Such inequality of access creates "social-ecological traps" that may drive disadvantaged fishermen to use more destructive technologies like dynamite (Cinner, 2011).

Technological solutions to fishery problems have been successful in the past and are less extreme and controversial than spatial closures or population control (Kennelly \& Broadhurst, 2002) so long as differential access is considered. Moreover, limiting the rights, space or number of fishermen may be ineffective if technological advances continue to increase catch efficiency (sometimes termed fishing power) and enforcement technology is inadequate. Therefore, we argue that Malthusian descriptions of, and prescriptions for, overfishing that ignore the effects of past technological advances and the role of future innovation may not solve the problem at hand.

\subsection{Demand and distribution}

Since the 1960s, annual per capita fish consumption globally has increased by nearly $10 \mathrm{~kg}$ (FAO 2014), and this trend is projected to continue in the coming decades (Merino et al., 2012; World Bank 2013). While common drivers of demand are attributed to population growth, urbanization and rising incomes (Delgado, Wada, Rosegrant, Meijer, \& Ahmed, 2003; Hall, Delaporte, Phillips, Beveridge, \& O'Keefe, 2011) particularly in developing countries, the largest portion of global demand for seafood still comes from markets in developed nations. Developed countries, encompassing a mere $12 \%$ of the world's population, consume $30 \%$ of the world's fish supply (Swartz et al., 2010). A handful of large transnational seafood corporations disproportionately control global marine catch (11-16\%) and associated stocks (19-40\%), exerting considerable force on global seafood production (Österblom et al., 2015). To satisfy demand in this era of globalization, many nations make use of distant water fleets and international markets to obtain products from other regions, contributing unintentionally to irresponsible fisheries practices that result in serious social and ecological consequences. 
Distant water fleets have enabled some countries to diversify their catch and satisfy demand using resources from international waters or the Exclusive Economic Zone's (EEZ) of other countries (Belhabib, Greer, \& Pauly, 2017; Pauly et al., 2013; Seto et al., 2017). Access to these waters is usually obtained through joint ventures or through third-party access agreements with central governments, which often lack support for sustainable fishing practices. Furthermore, the difficulty in achieving the commitment and cooperation of involved countries (Sumaila, Zeller, Watson, Alder, \& Pauly, 2007; Sumaila et al., 2015) consequently depletes many internationally managed stocks (Cullis-Suzuki \& Pauly, 2010; Juan-Jorda, Mosqueira, Cooper, Freire, \& Dulvy, 2011). Similarly, when a country pays a fee to use resources from another (usually developing) country's EEZ, the paying country often dictates the agreement, and the hosting country may lack the capacity to negotiate or enforce regulations. For example, European fishing activity in West Africa is often restricted through fishing effort (i.e. number of vessels), but not catch (Kaczynski \& Fluharty, 2002), allowing the industrial vessels to harvest an essentially unlimited volume of resources. These distant water fleets have an unfair advantage over local fishers and are more likely to contribute to overfishing of coastal resources; foreign vessels are equipped with powerful motors and technology that increase fleet capacity, and these fleets tend to have more political and economic power and thus preferential access (Bennett et al., 2015). Distant water fleets commonly operate as "roving bandits" (Berkes et al., 2006), moving on to other places when the fishery is not profitable, and therefore have few incentives to conserve local resources.

Beyond the effects of overfishing, distant water vessels fishing both in high seas and national waters of other countries compete for fish with local vessels, which are often small-scale with fishers highly dependent on fisheries for employment, livelihood and food security. This has been described by some as a form of "ocean grabbing," whereby local people are robbed of fisheries resources (Bennett et al., 2015). In addition, the unbalanced agreements and the negligible fees paid by the foreign vessels foster unfair fishing access, struggling local fisheries and domestic fishing industries, and loss of employment in the fishing sector (Alder \& Sumaila, 2004; Kaczynski \& Fluharty, 2002). Fisheries trade vis-à-vis globalization processes also has severe impacts on livelihoods. In many ways, developed countries have driven a change in consumer tastes, favoring convenience foods and high-value products, that are provided by cheap labour in developing countries (FAO 2012). With the incredible growth of seafood demand over the past five decades, local fishermen in developing countries export their high-end fish to maximize the profitability of their business. The high export unit values drive up domestic prices, depriving locals of this food source (Delgado et al., 2003).

In sum, with the globalization of the fishing industry, overfishing has become a prominent food security issue that affects people on every continent, and requires multilateral cooperation and compliance to secure the livelihood of millions and prevent the collapse of the fishing industry. While population growth may explain depletion of natural resources, recognition of the regional and national effects of demand and distribution in a globalized economy provides a more nuanced and political account of the processes driving overfishing.

\subsection{Marginalization and equity}

Building upon the theory advanced by modern development scholars (Bene, 2003), we argue that overfishing ought to be recognized as a breakdown in rights, access, tenure and management of marine resources rather than merely a failure in production associated with too many fishers 
chasing too few fish. Although fishing communities in developing countries are often characterized by austere living conditions and inadequate services, high levels of job satisfaction are reported by individuals who value their unique relationship with the marine environment, in addition to the autonomy and cultural identity associated with their occupation (Pollnac \& Poggie, 2008; Pollnac, Pomeroy, \& Harkes, 2001). A human-environment disconnect may be defined as the destruction of the physical, psychological, economic and political relationship between people and their environment as well as among each other (Nayak et al., 2014).

Following sweeping neoliberal reforms associated with the growth and globalization of the seafood trade, fishermen in many regions have seen traditions, values and social relations fundamental to their livelihoods subverted by externally imposed capitalism and class processes (Ibarra, Reid, \& Thorpe, 2000; St Martin, 2007). While rights-based approaches have been advocated as a means of controlling or reducing harvesting pressure, an "entitlement failure" has often occurred as property rights and political power have been aggregated by middle-men, and other market or political actors, at the expense of those individuals actively engaged in the harvest (Bene, 2003; Carothers, 2010; Mansfield, 2011). Rent-seeking interests and patron-client relation- ships have proliferated across the sector as fishers worldwide are increasingly dependent on local elites to access the credit, permits, and equipment required for their livelihoods (Amarasinghe, 1989; Basurto, Bennett, Weaver, Rodriguez-Van Dyck, \& AcevesBueno, 2013; Crona \& Bodin, 2010). Middlemen capture a large portion of the revenue generated by the sector, while channelling demand from international markets and making the critical decisions concerning where, when and what to fish (Crona, Nystrom, Folke, \& Jiddawi, 2010).

This organizational structure is increasingly criticized as unequal, exploitative and unsustainable (Nayak \& Berkes, 2010), and fishers who end up indebted due to resource scarcity may find themselves trapped in a "bonded labour" situation resembling feudal enterprise. Recently, severe violations of human rights have been exposed across the fishing sector in both developing and developed contexts through documented events of human trafficking and slavery (Urbina, 2015), revealing that some of the most persecuted populations in the world are involved in fishing (Kittinger et al., 2017). Although unscrupulous behaviour and monopolistic advantage among fisheries patrons is nothing new, we suggest that global market forces and neoliberal reforms have acted in concert to amplify and legitimize asymmetrical power distributions within the sector. In doing so, they threaten to undermine the cultural identity, local stewardship and capacity for collective action that has traditionally functioned to support marine socialecological systems.

Deprived of agency, the ability to make decisions and pursue objectives that fishermen themselves deem important and worthwhile, the behaviour of fishers can be driven by short-term utilitarian concerns rather than the extended outlook required for environmental stewardship. For example, fishers entrenched in poverty are more likely to use destructive fishing gear that destroys habitat and captures a higher proportion of juvenile fish, and target functionally important species that promote ecosystem integrity (Cinner, 2010). While fishers may be willing to take action to ensure resource sustainability, this concern may be overridden by preoccupations concerning who obtains the benefits from a fishery, who is responsible for resource degradation and who should bear the costs of regulation (Fabinyi, 2013). In sum, issues 
of equity and marginalization should not just be considered outcomes of overfishing but rather as structural processes contributing to overfishing as resource users worldwide are progressively alienated from the marine environment.

\subsection{Governance and management}

While the combination of good governance and effective management enable sustainable fisheries, policies intended to increase economic development and fisheries yields, or policies that are not sensitive to local context at the regional scale, can lead to overexploitation of fisheries and thus drive overfishing. The nation-state faces a difficult and paradoxical role complicating attempts at sustainable fisheries management, often because they are tasked with conserving fisheries resources for the public good and developing the harvest of these resources (Allison \& Ellis, 2001; Young, 2001). The latter task is characterized by a further tension between concerns for national economic growth and rent maximization, vs. providing fair and equitable access to fisheries resources and associated livelihoods. As a result, formal state-led fisheries policies can in fact drive overfishing irrespective of population growth pressures. For example, policies intended to develop underutilized fisheries resources often incentivize the influx of new fishers from other sectors or regions, overwhelming local social, institutional and ecological capacity for sustainable fishing and fomenting the "tragedy of incursion" (Ibarra et al., 2000; Young, 2001). Similarly, while important for maintaining access to resources and livelihoods particularly during difficult times, government subsidies can decouple the fishing sector from important economic signals (such as resource scarcity or rising fuel prices) (Sumaila, Teh, Watson, Tyedmers, \& Pauly, 2008), potentially contributing to overfishing (Munro \& Sumaila, 2002).

Furthermore, well-intended top-down policies that do not consider local context, such as existing political or institutional dynamics, can be derailed or lead to unintended social and ecological consequences. For example, a recent change in Mexican fisheries policy demonstrates that existing power asymmetries acting in concert with unequal distribution of formal rights may incentivize overfishing (Cinti et al., 2010). Similarly, the imposition of formal territorial use rights in Chile without consideration of existing informal institutions led to increased conflict among fishing constituents, and the erosion of trust, adaptive capacity and ecological resilience (Gelcich, Edwards-Jones, Kaiser, \& Castilla, 2006).

Perceived legitimacy, compliance and enforcement also dictate how policies play out in practice (i.e. effective management), mediate fishing effort, and influence social and ecological outcomes. Jentoft (2000) suggests that fisheries policies face a legitimacy crisis, largely because of the discrepancy between ideals and reality in policymaking, and because of the lack of opportunity for fishing sector participation in policy processes. In the absence of adequate enforcement capacity, fishers who decide to comply with formal policy either lose out to fishers getting away with rule-breaking, or become complicit in destructive and illegal behaviour (Cudney-Bueno \& Basurto, 2009; Raemaekers et al., 2011). Thus, even well-designed policies with some degree of perceived legitimacy can drive overfishing in the absence of informal or formal enforcement. Importantly, compliance is not necessarily black or white. We need to consider how rules and laws are developed and by whom, and the resulting impacts on social and economic inequalities and the environment (Hauck, 2008). Power plays a role in defining what constitutes environmental crime and the resulting winners and losers (Hauck, 2008; Oracion, 
Miller, \& Christie, 2005); traditional tenure rights can instantaneously become illegal and offlimits, with major implications for the ecological health of the fishery. In sum, inappropriate policies and ineffective management can often incentivize overfishing instead of reducing it.

Table 2. Mediating drivers of overfishing and related policy levers

\begin{tabular}{|l|l|}
\hline Driver & Policy Levers \\
\hline Technology and innovation & $\begin{array}{l}\text { Incentives for innovations } \\
\text { Fisher participation in innovation and testing of new } \\
\text { technology } \\
\text { Greater attention to differential access to technology }\end{array}$ \\
\hline Demand and distribution & $\begin{array}{l}\text { Ensuring equitable allocation and distribution of } \\
\text { licenses and rights to fish } \\
\text { Limiting leases of national waters to foreign vessels } \\
\text { Policies focusing on ensuring local food } \\
\text { security/sovereignty }\end{array}$ \\
\hline Marginalization and equity & $\begin{array}{l}\text { Consideration of development and human rights } \\
\text { goals in congruence with fisheries } \\
\text { Ensure rights and access to resources Address power } \\
\text { asymmetries and processes }\end{array}$ \\
\hline Governance and management & $\begin{array}{l}\text { Legitimacy of institutions to develop supportive } \\
\text { constituency } \\
\text { Respect for context and protection of pre-existing } \\
\text { institutions } \\
\text { Including fishers in governance processes (decision- } \\
\text { making, enforcement, monitoring, conflict } \\
\text { resolution) }\end{array}$ \\
\hline
\end{tabular}

\section{Discussion and Conclusion}

Instead of rejecting the dominant Malthusian overfishing narrative, we demonstrate the importance of creating space for a diverse and complementary dialogue with the potential to increase our capacity for effecting change and moving towards healthy, just and sustainable fisheries. Our four examples of intermediate drivers illustrate the pitfalls of Malthusian prescriptions and the potential for more nuanced, tractable policies (Table 2). The double-edged sword of technology promotes sustainability through innovation, but it can also increase catch efficiency and intensity through mechanization. High demand for seafood generated mostly by developed countries, and facilitated by a globalized economy, is depleting fish stocks in the EEZs of many developing countries, while threatening local livelihoods, food security and human rights. Issues of equity and marginalization are structural processes contributing to overfishing by progressively alienating many fishers from the marine environment and from political and economic opportunities. While good governance and effective management combined can enable sustainability of fisheries, some policies intended to increase economic development and fisheries production, or policies that are not sensitive to local context can instead drive overexploitation.

Importantly, the relative impacts of each of these drivers, and others, need to be treated as hypotheses and tested with empirical evidence in different contexts (Branch, 2015); these relationships should never be assumed, as the population-environment relationship so often is. As such, there will never be a panacea for addressing overfishing. The "scaling up" of marine 
governance solutions without knowledge of different contexts can lead to ineffective or inappropriately applied fisheries management policies or programmes. At worst, this will lead to perverse and counter-intuitive outcomes like those mentioned above.

Designing an effective response requires developing a holistic understanding of the diverse drivers of overfishing, hypothesis testing to identify the most relevant drivers responsible and choosing from corresponding available and salient fisheries management policies (see Table 2). For example, if destructive gear is the primary driver of overfishing, a closer look at differential access to fishing technology and permits can uncover potential systemic inequalities driving fisherman behaviour and gear utilization. Likewise, fisher involvement in innovation and testing of new technology can increase efficacy and uptake of new sustainable technologies (Jenkins, 2010). Addressing issues of demand and distribution may require national-level policies restricting access of distant water vessels, efforts to address the accumulation of licenses by corporations, or greater attention to ensure local fisheries adequately contribute to food and livelihood security. If the issues of marginalization and equity are important drivers of overfishing, effective fisheries policies may have to be codeveloped with well-designed poverty alleviation and development projects in accordance with human rights protocols (Allison et al., 2012; FAO 2015; Kittinger et al., 2013, 2017; Ratner, Åsgård, \& Allison, 2014; Weeratunge et al., 2014), and incorporate strategies designed to restore the connections between resources and people by shifting existing power and market dynamics (Nayak et al., 2014). Governance and management institutions can increase perceived legitimacy, compliance and fairness by involving fishers in policy processes and acknowledging local context and pre-existing norms and institutions and allow for more creative and flexible solutions to overfishing (Finkbeiner \& Basurto, 2015). It bears repeating that these are just four examples of the many complex drivers of overfishing. Any comprehensive fisheries policies effective at curbing overfishing will require more than stock assessments and autocratic decision-making, but rather assessment and evaluation of additional relevant local drivers, facilitated by the integration of social science data on fishing communities and cultures, as well as local stakeholders' knowledge, needs and beliefs.

Expanding the overfishing narrative beyond the lens of population growth explicitly reveals the role of power, politics, wealth and conflict in overfishing: differential access to technology, permits and markets; patron-client relationships contributing to bonded labour; fisher alienation from policy processes; competition between international, highly mechanized fleets and local fishers; and disproportionate consumption of seafood across geographies are all characterized by extreme power differentials and inequity. Narratives are often constructed by those in power with major implications for the powerless. As scientists, conservationists and policymakers, it is important for us to be critically self-aware of the possible neocolonial bias implicit in the narratives we advance and how it plays out on the ground in various contexts (Duarte et al., 2015). Attributing global fisheries declines to population growth is a potentially unfair and apolitical attribution of environmental degradation and is an easy way to export problems and responsibilities to other geographic and demographic contexts.

The practical contribution of this manuscript is to advance the idea that a reduction in the number of fishers is not the only way to solve overfishing. Rather, we can maintain livelihood and food security for small-scale fishers while advancing sustainability by addressing power imbalances and inequity. Equitable solutions can free fishers from "social-ecological traps," increasing their 
autonomy and flexibility to use less destructive gear, target more abundant stocks and retain more value (Cinner, 2010, 2011). Empirical studies have shown increased environmental stewardship and ecosystem health, with the same number of fishers, when collective rights and ownership are allocated to fishing communities (Fiske, 1992; Gelcich et al., 2008; Micheli et al., 2012). Thus, we argue that equity is necessary for sustainability, regardless of population growth or number of fishers.

We hope that by reconstructing the overfishing narrative in a more complex and nuanced fashion with explicit attention to the sociopolitical processes governing its intermediate drivers, we can constructively add to policy discussions and actions. We suggest reconsidering the blame placed upon fishers in contexts where access to the marine environment is a critical component of livelihoods and food security. The policy prescriptions designed to reduce access rights, harvesting rights and resource dependence of local populations may produce ethical and social ramifications with unintended environmental consequences. Finally, we suggest the importance of being critically self-aware in the creation and use of meta-narratives about humanenvironment relationships, arguing instead for a more holistic understanding of the drivers of overfishing. Rather than simply "scaling up" fisheries management and conservation policy prescriptions, empirical analysis of the drivers of overfishing in different contexts could guide the choice of more effective policies to address the challenge of overfishing. While we use fisheries as a case-study to explore these human-environment relationship assumptions, this debate continues to occur on a much broader scale across sectors and geographies; thus, we hope the message of this article is salient and useful in a broader context as we continue to work towards socially just and environmentally sustainable policy solutions.

\section{Acknowledgements}

We would like to thank Dr. Lisa Campbell for a prereview of this manuscript. NJB acknowledges financial support from the Banting and Liber Ero Postdoctoral Fellowship Programs.

\section{References}

Alder, J., \& Sumaila, U. R. (2004). Western Africa: A Fish Basket of Europe Past and Present. The Journal of Environment \& Development, 13, 156-178.

Allison, E. (2001). Big laws, small catches: Global ocean governance and the fisheries crisis. Journal of International Development, 13, 933-950.

Allison, E., \& Ellis, F. (2001). The livelihoods approach and management of small-scale fisheries. Marine Policy, 25, 377-388.

Allison, E. H., Ratner, B. D., Åsgård, B., Willmann, R., Pomeroy, R., \& Kurien,

J. (2012). Rights-based fisheries governance: From fishing rights to human rights. Fish and Fisheries, 13, 14-29.

Amarasinghe, O. (1989). Technical Change, Transformation of Risks and Patronage Relations in a Fishing Community of South Sri Lanka. Development and Change, 20, 701-733.

Basurto, X. (2005). How locally designed access and use controls can prevent the tragedy of the commons in a Mexican small-scale fishing community. Society and Natural Resources, $18,643-659$.

Basurto, X., Bennett, A., Weaver, A. H., Rodriguez-Van Dyck, S., \& Aceves- Bueno, J. S. (2013). Cooperative and Noncooperative Strategies for Small-scale Fisheries' Self- 
governance in the Globalization Era : Implications for Conservation. Ecology and Society, 18, 38 .

Belhabib, D., Greer, K., \& Pauly, D. (2017). Trends in Industrial and Artisanal Catch Per Effort in West African Fisheries. Conservation Letters, 1-10.

Bene, C. (2003). When fishing rhymes with poverty: A first step beyond the old paradigm on poverty in small-scale fisheries. World Development, 31, 949-975.

Bene, C., Barange, M., Subasinghe, R., Pinstrup-Andersen, P., Merino, G., Hemre, G. I., \& Williams, M. (2015). Feeding 9 billion by 2050 - Putting fish back on the menu. Food Security, 7, 261-274.

Bennett, N. J., \& Dearden, P. (2014). Why local people do not support conservation: Community perceptions of marine protected area livelihood impacts, governance and management in Thailand. Marine Policy, 44, 107-116.

Bennett, N. J., Govan, H., \& Satterfield, T. (2015). Ocean grabbing. Marine Policy, 57, 61-68.

Berkes, F. (2003). Alternatives to Conventional Management: Lessons from Small-Scale Fisheries. Environments, 31, 5.

Berkes, F., \& Folke, C. (1998) Linking social and ecological systems: Management practices and social mechanisms for building resilience. Cambridge: Cambridge University Press.

Berkes, F., Hughes, T. P., Steneck, R. S., Wilson, J. A., Bellwood, D. R., Crona, B., ... Nyström, M. (2006). Globalization, roving bandits, and marine resources. Science, 311, 15571558.

Blaikie, P., \& Brookfield, H. (2015) Land degradation and society. New York, NY: Routledge Revivals.

Borgerhoff-Mulder, M., \& Copolillo, P. (2005). Conservation: Linking ecology, economics and culture. Princeton: Princeton University Press.

Boserup, E. (1965). The conditions of agricultural growth: The economics of agrarian change under population pressure. London: Allen and Un-win.

Branch, T. A. (2015). Fishing Impacts on Food Webs: Multiple Working Hypotheses. Fisheries, $40,373-375$.

Bromley, D. W. (2009). Abdicating Responsibility: The Deceits of Fisheries Policy. Fisheries, $34,280-290$.

Campbell, J. (1999). Linking the sustainable livelihood approach and the code of conduct for responsible fisheries. Exeter: Sustainable Fisheries Livelihood Project.

Carothers, C. (2010). Tragedy of commodification: Displacements in Alutiiq fishing communities in the Gulf of Alaska. MAST, 9, 95-120.

Cinner, J. E. (2010). Poverty and the use of destructive fishing gear near east African marine protected areas. Environmental Conservation, 36, 321-326.

Cinner, J. E. (2011). Social-ecological traps in reef fisheries. Global Environmental Change, 21, $835-839$.

Cinner, J. E., Huchery, C., MacNeil, M. A., Graham, N. A., McClanahan, T. R., Maina, J., ... Allison, E. H. (2016). Bright spots among the world's coral reefs. Nature, 535, 416-419.

Cinti, A., Shaw, W. W., Cudney-Bueno, R., \& Rojo, M. (2010). The unintended consequences of formal fisheries policies: Social disparties and resource overuse in a major fishing community in the Gulf of California, Mexico. Marine Policy, 34, 328-339.

Costa-Pierce, B. (2008). An ecosystem approach to marine aquaculture: A global review. In D. Soto, J. Aguilar-Manjarrez, \& N. Hishamunda (Eds.), Building an ecosystem approach to aquaculture (pp. 81-115). Rome: FAO. 
Cote, M., \& Nightingale, A. J. (2012). Resilience thinking meets social theory: Situating social change in socio-ecological systems (SES) research. Progress in Human Geography, 36, $475-489$.

Crona, B., \& Bodin, Ö. (2010). Power asymmetries in small-scale fisheries: A barrier to governance transformability? Ecology and Society, 15, 32.

Crona, B., Nystrom, M., Folke, C., \& Jiddawi, N. (2010). Middlemen, a critical social-ecological link in coastal communities of Kenya and Zanzibar. Marine Policy, 34, 761-771.

Cudney-Bueno, R., \& Basurto, X. (2009). Lack of cross-scale linkages re- duces robustness of community-based fisheries management. PLoS One, 4, e6253.

Cullis-Suzuki, S., \& Pauly, D. (2010). Failing the high seas: A global evaluation of regional fisheries management organizations. Marine Policy, 34, 1036-1042.

Delgado, C., Wada, N., Rosegrant, M., Meijer, S., \& Ahmed, M. (2003). Fish to 2020: Supply and demand in changing global markets. Washington DC: International Food Policy Research Institute.

Dietz, T., Ostrom, E., \& Stern, P. C. (2003). The struggle to govern the commons. Science, 302, 1907-1912.

Duarte, C. M., Fulweiler, R. W., Lovelock, C. E., Martinetto, P., Saunders, M. I., Pandolfi, J. M., ... Nixon, S. W. (2015). Reconsidering ocean calamities. BioScience, 65, 130-139.

Durham, W. (1995). Political ecology and environmental destruction in Latin America. In M. Painter(Ed.), The social causes of environmental destruction in Latin America (pp 249264). Ann Arbor, MI: University of Michigan Press.

Ehrlich, P. (1968). The population bomb. New York: Ballantine.

Essington, T. E., Beaudreau, A. H., \& Wiedenmann, J. (2006). Fishing through marine food webs. Proceedings of the National Academy of Sciences of the United States of America, 103, 3171-3175.

Evans, R. (2016). Conservation and birth control: A controversial mix? Retrived from http://news.mongabay.com/2016/03/ conservation-and-birth-control-a-controversial$\mathrm{mix} /$ ?n3wsletter.

Fabinyi, M. (2013). Social relations and commodity chains: The live reef fish for food trade. Anthropological Forum A Journal of Social Anthropology and Comparative Sociology, 23, 36-57.

Fabinyi, M., Evans, L., \& Foale, S. J. (2014). Social-ecological systems, social diversity, and power: Insights from anthropology and political ecology. Ecology and Society, 19, 28.

FAO (2012). State of World Fisheries and Aquaculture. Rome, Italy: FAO. FAO (2014). The State of World Fisheries and Aquaculture: Opportunities and Challenges. Rome, Italy: FAO.

FAO (2015). Voluntary guidelines for securing sustainable small-scale fisheries. Rome, Italy: FAO.

Finkbeiner, E. M., \& Basurto, X. (2015). Re-defining co-management to facilitate small-scale fisheries reform: An illustration from northwest Mexico. Marine Policy, 51, 433-441.

Fiske, S. J. (1992). Sociocultural aspects of establishing marine protected areas. Ocean \& Coastal Management, 18, 25-26.

Gelcich, S., Edwards-Jones, G., Kaiser, M. J., \& Castilla, J. C. (2006). Co- management Policy Can Reduce Resilience in Traditionally Managed Marine Ecosystems. Ecosystems, 9, 951-966. 
Gelcich, S., Kaiser, M. J., Castilla, J. C., \& Edwards-Jones, G. (2008). Engagement in comanagement of marine benthic resources influences environmental perceptions of artisanal fishers. Environmental Conservation, 35, 36-45.

Gordon, H. S. (1954). The Economic Theory of a Common-Property Resource: The Fishery. Journal of Political Economy, 62, 124-142.

Gray, L. C., \& Moseley, W. G. (2005). A geographical perspective on poverty- environment interactions. The Geographical Journal, 171, 9-23.

Hall, S. J., Delaporte, A., Phillips, M. J., Beveridge, M., \& O'Keefe, M. (2011). Blue frontiers: Managing the environmental costs of aquaculture. Malaysia: Penang.

Hardin, G. (1968). The Tragedy of the Commons. Science, 162, 1243-1248. Harris, A., Mohan, V., Flanagan, M., \& Hill, R. (2012). Integrating family planning service provision into community-based marine conservation.

Oryx, 46, 179-186.

Hartmann, B. (2004). Conserving racism: The greening of hate at home and abroad. Different Takes, 27, 1-4.

Hauck, M. (2008). Rethinking small-scale fisheries compliance. Marine Policy, 32, 635-642.

Hilborn, R. (2007). Reinterpreting the state of fisheries and their management. Ecosystems, 10, $1362-1369$.

Ibarra, A. A., Reid, C., \& Thorpe, A. (2000). Neo-liberalism and its impact on overfishing and overcapitalisation in the marine fisheries of Chile, Mexico and Peru. Food Policy, 25, 599-622.

Jackson, J. B. (2001). What was natural in the coastal oceans? Proceedings of the National Academy of Sciences of the United States of America, 98, 5411-5418.

Jackson, J. B., Kirby, M. X., Berger, W. H., Bjorndal, K. A., Botsford, L. W., Bourque, B. J., ... Hughes, T. P. (2001). Historical overfishing and the recent collapse of coastal ecosystems. Science, 293, 629-637.

Jenkins, L. D. (2010). Profile and influence of the successful fisher-inventor of marine conservation technology. Conservation and Society, 8, 44.

Jentoft, S. (2000). Legitimacy and disappointment in fisheries management. Marine Policy, 24, 141-148.

Johnson, A. F., Moreno-Baez, M., Giron-Nava, A., Corominas, J., Erisman, B., Ezcurra, E., \& Aburto-Oropeza, O. (2017). A spatial method to calculate small-scale fisheries effort in data poor scenarios. PLoS One, 12, 1-17. Johnson, V., \& Nurick, R. (1995). Behind the headlines: The ethics of the population and environment debate. International Affairs (Royal Institute

of International Affairs, 71, 547-565.

Juan-Jorda, M. J., Mosqueira, I., Cooper, A. B., Freire, J., \& Dulvy, N. K. (2011). Global population trajectories of tunas and their relatives. Proceedings of the National Academy of Sciences of the United States of America, 108, 20650-20655.

Kaczynski, V. M., \& Fluharty, D. L. (2002). European policies in West Africa: Who benefits from fisheries agreements? Marine Policy, 26, 75-93.

Kennelly, S. J., \& Broadhurst, M. K. (2002). By-catch begone: Changes in the philosophy of fishing technology. Fish and Fisheries, 3, 340-355.

Kittinger, J. N., Finkbeiner, E. M., Ban, N. C., Broad, K., Carr, M. H., Cinner, 
J. E., ... Fujita, R. (2013). Emerging frontiers in social-ecological systems research for sustainability of small-scale fisheries. Current Opinion in Environmental Sustainability, $5,352-357$.

Kittinger, J. N., Teh, L. C., Allison, E. H., Bennett, N. J., Crowder, L. B., Finkbeiner, E. M., ... Young, J. (2017). Committing to socially responsible seafood. Science, 356, 912-913.

Kremer, M. (1993). Population Growth and Technological Change: One Million B.C. to 1990. Quarterly Journal of Economics, 108, 681-716.

Lele, S., Wilshusen, P., Brockington, D., Seidler, R., \& Bawa, K. (2010). Beyond exclusion: Alternative approaches to biodiversity conservation in the developing tropics. Current Opinion in Environmental Sustainability, 2, 94-100.

Lohmann, L. (2003). Re-Imagining the Population Debate. The Corner House Briefing, 28, 120.

Malthus, T. (1798). An essay on the principle of population, as it affects the future improvement of society. St. Paul's Church-yard, London: The Lawbook Exchange, Ltd.

Mansfield, B. (2007). Property, markets, and dispossession: The western Alaska community development quota as neoliberalism, social justice, both, and neither. Antipode, 39, 479499.

Mansfield, B.. (2011) Modern industrial fisheries and the crisis of overfishing. In R. Peet, P. Robbins \& M. Watts (Eds.), Global Political Ecology (pp 84-99). London: Routledge.

McClanahan, T. R., Hicks, C. C., \& Darling, E. S. (2008). Malthusian overfishing and efforts to overcome it on Kenyan coral reefs. Ecological Applications, 18, 1516-1529.

McKee, J. K., Sciulli, P. W., David Fooce, C., \& Waite, T. A. (2004). Forecasting global biodiversity threats associated with human population growth. Biological Conservation, $115,161-164$.

Meadows, D. H. (1972). The Limits to Growth; A Report for the Club of Rome's Project on the Predicament of Mankind. New York, NY: Universe Books.

Merino, G., Barange, M., Blanchard, J. L., Harle, J., Holmes, R., Allen, I., ... Jennings, S. (2012). Can marine fisheries and aquaculture meet fish demand from a growing human population in a changing climate? Global Environmental Change, 22, 795-806.

Micheli, F., Saenz-Arroyo, A., Greenley, A., Vazquez, L., Espinoza Montes,

J. A., Rossetto, M., \& De Leo, G. (2012). Evidence that marine reserves enhance resilience to climatic impacts. PLoS One, 7, e40832.

Morato, T., Watson, R., Pitcher, T. J., \& Pauly, D. (2006). Fishing down the deep. Fish and Fisheries, 7, 24-34.

Munro, G., \& Sumaila, U. R. (2002). The impact of subsidies upon fisheries management and sustainability: The case of the North Atlantic. Fish and Fisheries, 3, 233-250.

Nayak, P., \& Berkes, F. (2010). Whose marginalisation? Politics around environmental injustices in India's Chilika lagoon. Local Environment, 15, 553-567.

Nayak, P., Oliveira, L., \& Berkes, F. (2014). Resource degradation, marginalization, and poverty in small-scale fisheries: Threats to social-ecological resilience in India and Brazil. Ecology and Society, 19, 73.

Newman, K., Fisher, S., Mayhew, S., \& Stephenson, J. (2014). Population, sexual and reproductive health, rights and sustainable develop- ment: Forging a common agenda. Reproductive Health Matters, 22, 53-64. 
Oglethorpe, J., Honzak, C., \& Margoluis, C. (2008). Healthy people healthy ecosystems: A manual on integrating health and family planning into conservation projects. Washington DC: World Wildlife Fund.

Oldham, J. (2006). Rethinking the Link: A Critical Review of Population-Environment Programs. Amherst, MA: Hampshire College Political Ecology Research Institute, University of Massachusetts.

Oracion, E. G., Miller, M. L., \& Christie, P. (2005). Marine protected areas for whom? Fisheries, tourism, and solidarity in a Philippine community. Ocean \& Coastal Management, 48, 393-410.

Osborn, F. (1948). Our plundered planet. London: Faber and Faber.

O'Shea, B., \& Thompson, S. (2006). The innovative application of vessel monitoring systems for the effective fisheries monitoring control and surveillance. ICES Document CM, 11, 125.

Österblom, H., Jouffray, J.-B., Folke, C., Crona, B., Troell, M., Merrie, A., \& Rockström, J. (2015). Transnational corporations as "keystone actors" in marine ecosystems. PLoS One, 10, e 0127533.

Ostrom, E. (1990). Governing the Commons. New York: Cambridge University Press.

Pauly, D. (1990). On Malthusian overfishing. Naga, the ICLARM Quarterly, 13, 3-4.

Pauly, D. (1994). From growth to malthusian overfishing: Stages of fisheries resources misuse. Traditional Marine Resource Management and Knowledge Information Bulletin, 3, 7-14.

Pauly, D. (2006). Major Trends in Small-Scale Marine Fisheries, with Emphasis on Developing Countries, and Some Implication for Social Sciences. Maritime Studies, 4, 7-22.

Pauly, D., Belhabib, D., Blomeyer, R., Cheung, W. W., Cisneros-Montemayor, A. M., Copeland, D., ... Österblom, H. (2013) China's distant-water fish- eries in the 21 st century. Fish and Fisheries, 15, 474-488.

Pauly, D., Christensen, V., Dalsgaard, J., Froese, R., \& Torres, F. Jr (1998). Fishing down the food webs. Science, 279, 860-863.

Pinkerton, E., \& Edwards, D. N. (2009). The elephant in the room: The hidden costs of leasing individual transferable fishing quotas. Marine Policy, 33, 707-713.

Pitcher, T. (2001). Fisheries managed to rebuild ecosystems? Reconstructing the past to salvage the future. Ecological Applications, 11, 601-617.

Pollnac, R. B., \& Poggie, J. J. (2008). Happiness, well-being and psychocultural adaptation to the stresses associated with marine fishing. Human Ecology Review, 15, 194-200.

Pollnac, R. B., Pomeroy, R. S., \& Harkes, I. H. T. (2001). Fishery policy and job satisfaction in three southeast asian fisheries. Ocean and Coastal Management, 44, 531-544.

Pomeroy, R. S., Pollnac, R. B., Katon, B. M., \& Predo, C. D. (1997). Evaluating factors contributing to the success of community-based coastal resource management: The Central Visayas Regional Project-1, Philippines. Ocean \& Coastal Management, 36, $97-$ 120.

Presidential Task Force (2015). Presidential Task Force on Combating IUU Fishing and Seafood Fraud: Action Plan for Implementing the Task Force Recommendations.

Raemaekers, S., Hauck, M., Bürgener, M., Mackenzie, A., Maharaj, G., Plagányi, É. E., \& Britz, P. J. (2011). Review of the causes of the rise of the illegal South African abalone fishery and consequent closure of the rights-based fishery. Ocean and Coastal Management, 54, $433-445$. 
Ratner, B. D., Åsgård, B., \& Allison, E. H. (2014). Fishing for justice: Human rights, development, and fisheries sector reform. Global Environmental Change, 27, 120-130.

Robbins, P. (2011). Political ecology: A critical introduction, 16th edn. West Sussex: John Wiley \& Sons.

Roberts, C. M. (1995). Effects of fishing on the ecosystem structure of coral reefs. Conservation Biology, 9, 988-995.

Seto, K., Belhabib, D., Mamie, J., Copeland, D., Vakily, J. M., Seilert, H., ... Pauly, D. (2017). War, fish, and foreign fleets: The marine fisheries catches of Sierra Leone 1950-2015. Marine Policy, 83, 153-163.

Smith, I. (1979). Traditional fisheries development in the Philippines. ICLARM Newsletter, 2, $16-18$.

St Martin, K. (2007). The difference that class makes: Neoliberalization and non-capitalism in the fishing industry of new england. Antipode, 39, 527-549.

Steneck, R. S. (2009). Marine conservation: Moving beyond Malthus. Current Biology, 19, 117119.

Sumaila, U. R., Lam, V. W., Miller, D. D., Teh, L., Watson, R. A., Zeller, D., ... Sala, E. (2015). Winners and losers in a world where the high seas is closed to fishing. Scientific Reports, 5,8481 .

Sumaila, U. R., Teh, L., Watson, R., Tyedmers, P., \& Pauly, D. (2008). Fuel price increase, subsidies, overcapacity, and resource sustainability. ICES Journal of Marine Science, 65, 832-840.

Sumaila, U. R., Zeller, D., Watson, R., Alder, J., \& Pauly, D. (2007). Potential costs and benefits of marine reserves in the high seas. Marine Ecology Progress Series, 345, 305-310.

Swartz, W., Rashid Sumaila, U., Watson, R., \& Pauly, D. (2010). Sourcing seafood for the three major markets: The EU, Japan and the USA. Marine Policy, 34, 1366-1373.

Torell, E., Crawford, B., Kotowicz, D., Herrera, M. D., \& Tobey, J. (2010). Moderating our expectations on livelihoods in ICM: Experiences from Thailand, Nicaragua, and Tanzania. Coastal Management, 38, 216-237. Toth, G., \& Szigeti, C. (2016). The historical ecological footprint: From overpopulation to over-consumption. Ecological Indicators, 60, 283-291.

Urbina, I.. (2015) Outlaw Ocean. New York, NY: New York Times.

Vitousek, P. M., Mooney, H. A., Lubchenco, J., \& Melillo, J. M. (2008). Human domination of Earth's ecosystems. Urban Ecology: An International Perspective on the Interaction Between Humans and Nature, 277, 3-13.

Vogt, W. (1948). Road to survival. New York: William Sloane Associates. Watson, R., Nowara, G. B., Hartmann, K., Green, B. S., Tracey, S. R., \&

Carter, C. G. (2015). Marine foods sourced from farther as their use of global ocean primary production increases. Nature Communications, 6, 7365.

Weeratunge, N., Béné, C., Siriwardane, R., Charles, A., Johnson, D., Allison,

E. H., ... Badjeck, M. C. (2014). Small-scale fisheries through the well- being lens. Fish and Fisheries, 15, 255-279.

World Bank Group. (2013). Fish to 2030: Prospects for fisheries and aqua- culture. Agriculture and Environmental Services Discussion Paper, 3, 102. Worm, B., Barbier, E. B., Beaumont, N., Duffy, J. E., Folke, C., Halpern, B. S., ... Sala, E. (2006). Impacts of Biodiversity Loss on Ocean Ecosystem Services. Science, 314, 787-790.

Worm, B., \& Branch, T. A. (2012). The future of fish. Trends in Ecology \& Evolution, 27, 1-6. 
Worm, B., Hilborn, R., Baum, J. K., Branch, T. A., Collie, J. S., Costello, C., ... Jensen, O. P. (2009). Rebuilding Global Fisheries. Science, 325, 578-585.

Young, E. (2001). State intervention and abuse of the commons: Fisheries development in Baja California Sur, Mexico. Annals of the Association of American Geographers, 91, 283306. 